\title{
In vitro evaluation of fungicides against Colletotrichum gloeosporioides (Penz.) Penz and Sacc. causing anthracnose of pomegranate (Punica granatum L.)
}

\author{
Devanshu Dev ${ }^{1}$ and T. Narendrappa \\ Kendra, Bengaluru- 560065, INDIA \\ ${ }^{*}$ Corresponding author. E-mail: dev9105@gmail.com \\ Received: January 21, 2016; Revised received: October 11, 2016; Accepted: December 4, 2016
}

${ }^{1}$ Department of Plant Pathology, College of Agriculture, University of AgriculturalSciences, Gandhi Krishi Vigyan

\begin{abstract}
Pomegranate (Punica granatum L.) is a widely grown fruit in many regions of the world. Anthracnose of pomegranate is one of the limiting factor for low productivity and also the low market price. Therefore, the management of anthracnose disease is necessary. In this study new fungicide molecules are evaluated under in vitro condition against the mycelial growth of Colletotrichum gloeosporioides. In vitro screening of fungicides against $C$. gloeosporioides showed two combination product Hexaconazole + Zineb, Trifloxystrobin + Tebuconazole and a nonsystemic fungicide Captan showed cent percent inhibition at 100, 250, 500 and 1000 ppm concentration. Similarly, systemic fungicides Hexaconazole, Propiconazole, Penconazole, Tebuconazole and Carbendazim showed cent percent mycelial inhibition at 500, 1000 and 2000 ppm concentrations.
\end{abstract}

Keyword: Anthracnose, Colletotrichum, Fungicides, Pomegranate

\section{INTRODUCTION}

Pomegranate (Punica granatum L.) is an ancient beloved plant and fruit. Pomegranate is regarded as "fruit of paradise". Pomegranate and its usage are deeply embedded in human history, and utilization is found in many ancient human cultures as food and as a medical remedy.As a commercial crop, pomegranate is grown to a limited extent in selected locations in many states of India. Maharashtra accounts for more than two third area, while other states like Karnataka, Andhra Pradesh, Gujarat, Rajasthan and Tamilnadu share the rest. Maharashtra is the leading producer of pomegranate. The estimated area under pomegranate cultivation in India is about 1, 30,750 ha with the production of 13, 45,720 tons during 2013-14. Karnataka accounts 15,100 ha area and 1, 50,300 tons production in 201213 (Anonymous, 2014). According to the data published by National Horticulture Board of India there is an undersized decrease in the area of pomegranate cultivation in India from 109 thousand ha in 2008-09 to 107 thousand ha in $2010-11$; similarly, the production has decreased from 807 thousand tons to 743 thousand tons during the same period. Export of pomegranate has decreased in quantity from 35175.17 tons in 2007-08 to 30158.59 tons in 2011-12 (APEDA, 2011-12).

Anthracnose of pomegranate caused by Colletotrichum gloeosporioides (Penz.) Penz and Sacc. The symptoms on leaves observed as pinhead size of black to brown water soaked spots with circular margin. In advanced stage, these spots enlarged, coalesced and resulted in bigger patches. In severe case, leaves dried up and drooped down. On fruits, brown spherical depressed spots occurred in scattered form on the pericarp. In advanced stage, these spots coalesced to form necrotic patches over the surface of the fruit (Jayalaxami, 2010). Anthracnose of pomegranate is one of the contributing factors for this low productivity and large revenue losses. The management of anthracnose disease is necessary because of heavy losses, but there are number of chemicals available in the market as fungicides and their bio efficacy and suitability needs to be verified by in vitro and field studies. Therefore, in the present study we tried to find out in vitro effectiveness of different systemic and non-systemic chemicals at different concentration against $C$. gloeosporioides fungus. This study provide the suitable chemicals and concentration against $C$. gloeosporioides fungus. However, these chemicals need to be verified under field condition before farmer recommendation.

\section{MATERIALS AND METHODS}

The studies were carried out at Department of Plant Pathology, University of Agricultural Sciences, Bengaluru. The pathogen was isolated from the pomegranate (Punica granatum L.) leaves and fruits showing typical anthracnose symptoms by standard tissue isolation method and further purified by single spore isolation method (Rangaswami and Mahadevan, 1999) on potato dextrose agar medium (PDA). The pathogen was identified based on its mycelial, conidial characteristics following standard mycological keys (Barnett and 
Hunter, 1972) and were maintained separately on PDA for further experiments.

In vitro evaluation of fungicides against $C$. gloeosporioides: The efficacy of three non-systemic viz., Captaf 50 WP (Captan), Kavach 75 WP (Chlorothalonil) and Dithane M- 4575 WP (Mancozeb), three combination product viz., Avatar 72 WP (Hexaconazole 4\% + Zineb 68\%), Nativo 75 WG (Trifloxystrobin + Tebuconazole) and Sectin 60 WG (Fenamidone 10\% + Mancozeb 50\%) and nine systemic fungicides viz., Amistar $25 \mathrm{SC}$ (Azoxystrobin), Score 25 SC (Difenoconazole), Bavistin 50 WP (Carbendazim), Contaf 5 EC (Hexaconazole), Tilt 25 EC (Propiconazole), Topenco 100 EC (Penconazole), Pulsor 24 SC (Thifluzamide), Compass 50 WG (Trifluoxystrobin) and Folicur $430 \mathrm{SC}$ (Tebuconazole) were tested against $C$. gloeosporioides for radial growth inhibition on the potato dextrose agar media using poisoned food technique under in vitro condition (Shravelle, 1961). The percent inhibition of growth of the test fungus was calculated by using the formula of Vincent (1947). The non-systemic fungicides were tried at 100, 250, 500 and $1000 \mathrm{ppm}$, whereas systemic fungicides were tried at 500, 1000, 2000 ppm concentrations. All the data were analysed by ANOVA (CRD 2 factorial design) after transforming the \% values to corresponding angular values.

\section{RESULTS}

In vitro evaluation of non-systemic/combination fungicides against $\boldsymbol{C}$. gloeosporioides: The inhibition of mycelial growth of $C$. gloeosporioides at four different concentration (100 ppm, $250 \mathrm{ppm}, 500 \mathrm{ppm}$ and $1000 \mathrm{ppm}$ ) of three non-systemic fungicides and three combination product was recorded and presented in
Table 1a.

Cent percent growth inhibition of $C$. gloeosporioides was recorded in combination product Hexaconazole + Zineb, Trifloxystrobin + Tebuconazole and nonsystemic fungicide Captan at all four concentrations. Least percent inhibition was noticed in Chlorothalonil (37.71\%). However, maximum percent inhibition of mycelial growth was at $1000 \mathrm{ppm}$ concentration irrespective of fungicides (Table 1a).

At 1000 ppm concentration all combination product viz., Hexaconazole + Zineb, Trifloxystrobin + Tebuconazole and Fenamidone + Mancozeb showed cent percent mycelial growth inhibition. However, nonsystemic fungicides, Captan showed cent percent mycelial inhibition followed by Mancozeb (47.48\%) and Chlorothalonil (55.88\%)

In vitro evaluation of systemic fungicides against $\boldsymbol{C}$. gloeosporioides: The inhibition of mycelial growth of C. gloeosporioides at three different concentrations (500 ppm, $1000 \mathrm{ppm}$ and $2000 \mathrm{ppm}$ ) of nine systemic fungicides was recorded and $\%$ inhibition is presented in Table $1 \mathrm{~b}$.

It was observed that, fungicides concentrations and their interaction differed significantly (at 1\% level of significance) with respect to inhibition of the mycelial growth of C. gloeosporioides.

Among nine systemic fungicides tested, maximum inhibition of growth of C. gloeosporioides was observed cent percent in Carbendazim, Hexaconazole, Propiconazole, Penconazole and Tebuconazole treated plates at all concentration (500 ppm, 1000ppm and $2000 \mathrm{ppm}$ ), Which were significantly (at 1\% level of significance) superior to all other fungicides followed by Difenoconazole $(84.84 \%)$, Trifluoxystrobin

Table 1a. In vitro evaluation of non-systemic/ combi fungicides against $C$. gloeosporioides.

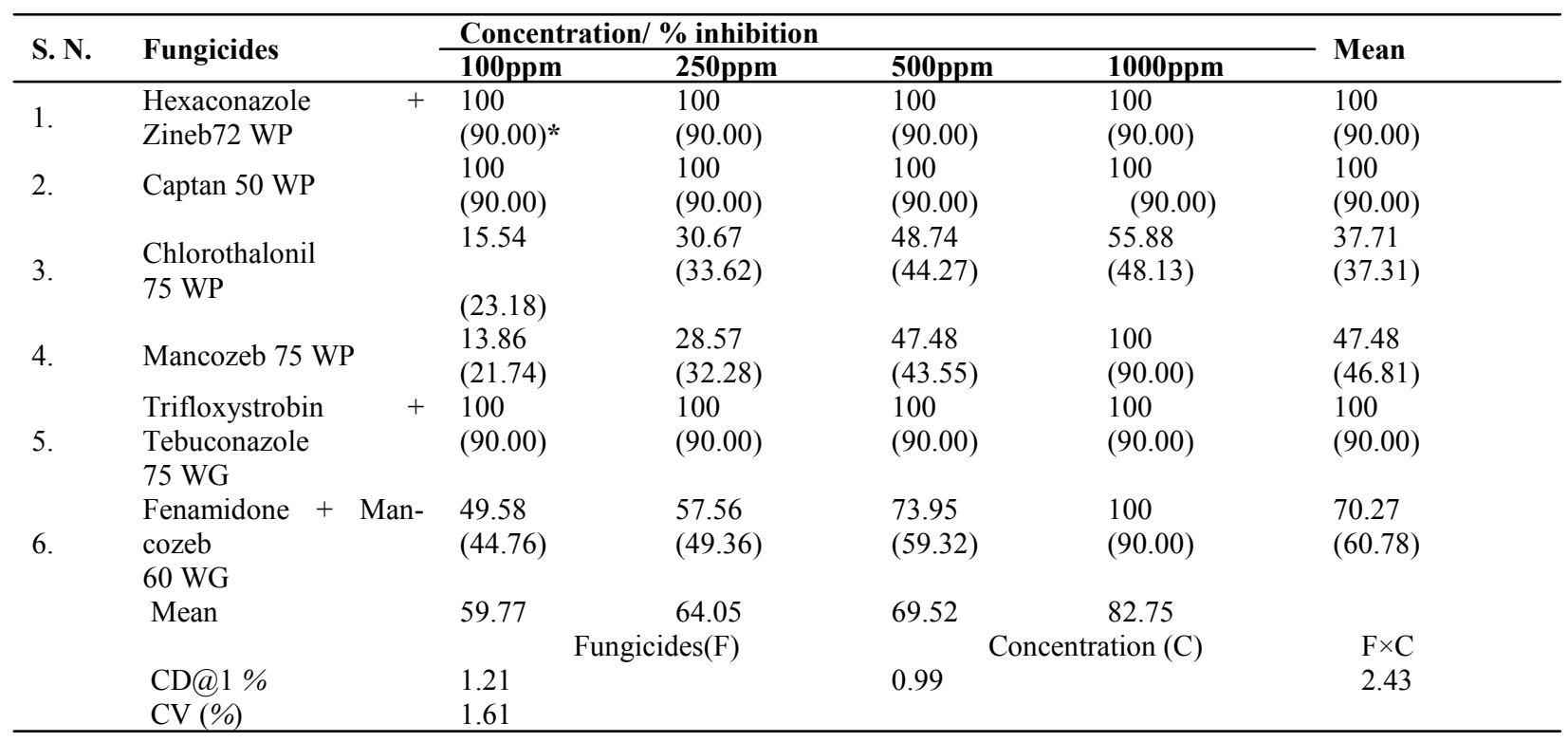

*Arcsine transformed values of percent inhibition. All values are mean of three replicates. 
Table 1b. In vitro evaluation of systemic fungicides against $C$. gloeosporioides.

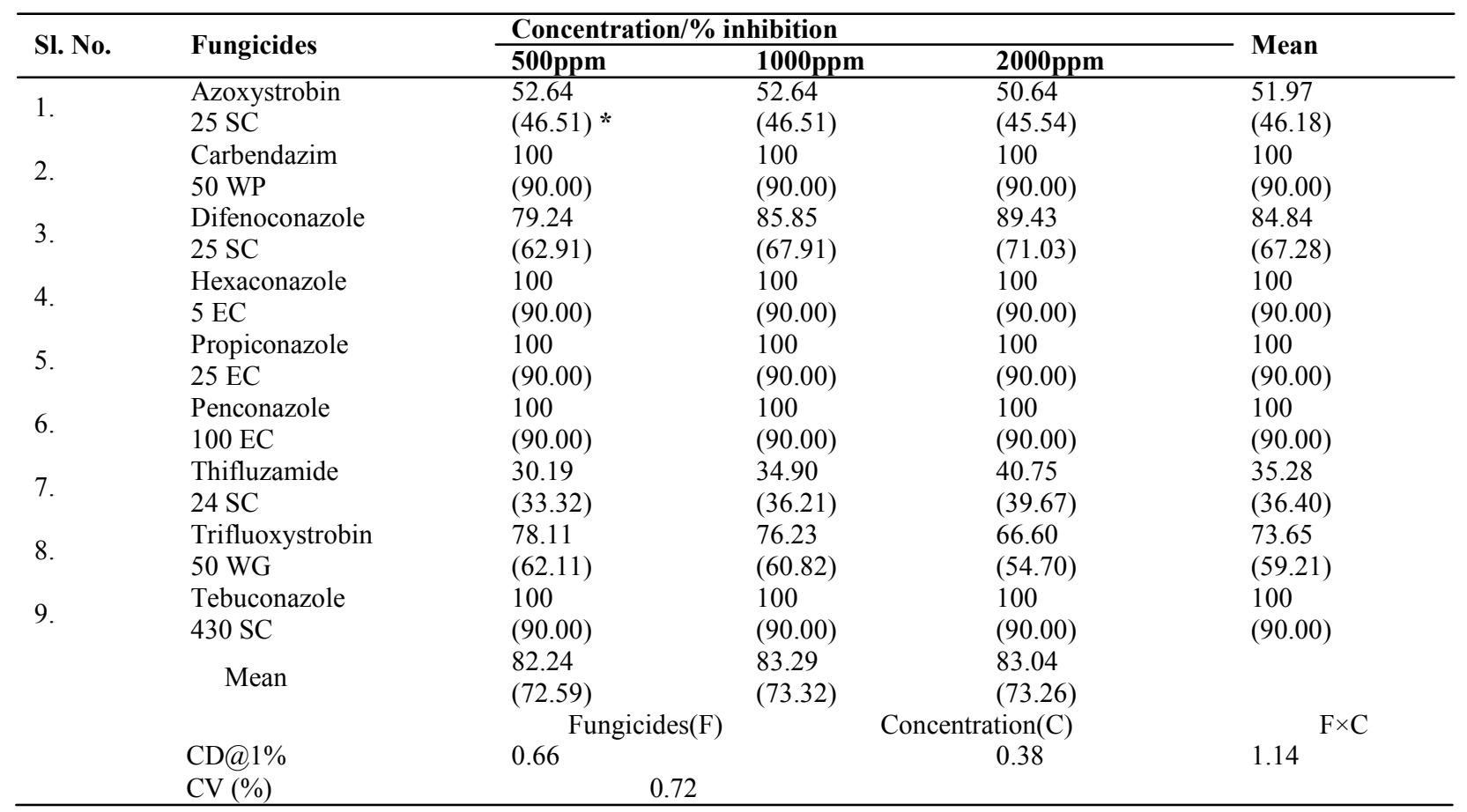

*Arcsine transformed values of percent inhibition. All values are mean of three replicates.

(73.65\%) and Azoxystrobin (51.97\%). The least percent inhibition of fungus was recorded in Thifluzamide (35.28\%).

Among the three tested concentrations (500ppm, $1000 \mathrm{ppm}$ and 2000ppm), $2000 \mathrm{ppm}$ concentration (83.04\%) was on par with 1000 ppm $(83.29 \%)$ concentration followed by 500 ppm (82.24\%). At 2000 ppm concentration, Carbendazim, Hexaconazole, Propiconazole, Penconazole and Tebuconazole showed cent percent mycelial growth inhibiton of C. gloeosporioides followed by Difenoconazole $(89.43 \%)$, Trifluoxystrobin (66.60\%), Azoxystrobin (50.64\%) and Thifluzamide (40.75\%) (Table 1b).

The mycelial growth inhibition of Azoxystrobin fungicides was found on par at 500ppm, $1000 \mathrm{ppm}$ and 2000 ppm concentration. Although, Trifluoxystrobin was also found on par at 500 ppm and 1000 ppm concentration.

\section{DISCUSSION}

In vitro evaluation of fungicides: There are lacks of resistant cultivars against various diseases. Therefore, the use of fungicides is one of the disease management practices. When there is outbreak of epidemic for any reason perhaps the use of fungicides is one of the best options available. These fungicides have to be used judiciously according to the need. Availability of various new fungicides in the market necessitates its evaluation under in vitro conditions to know their efficacy, and initiate spray schedule in field conditions (Jayalaxami, 2010).
In vitro evaluation of new synthetic molecules of fungicides is very much necessary before they are tried under field condition. Among the tested fungicides maximum percent inhibition (100\%) of C. gloeosporioides was recorded in combination product Hexaconazole + Zineb, Trifloxystrobin + Tebuconazole and nonsystemic fungicide Captan at all four concentration. Least \% inhibition was noticed in Chlorothalonil (37.71\%). Ekbote et al. (1996) reported that among the four fungicides tested against mango anthracnose caused by C. gloeosporioides Carbendazim + Mancozeb gave cent percent inhibition of mycelial growth at $0.1 \%$ concentration. Least percent inhibition of mycelial growth was observed in Chlorothalonil at all the tested concentration.

Among the nine systemic fungicides tested, maximum percent inhibition of growth of $C$. gloeosporioides was observed cent percent in Carbendazim, Hexaconazole, Propiconazole, Penconazole and Tebuconazole treated plates at all concentration. However, the least percent inhibition of fungus was recorded in Thifluzamide $(35.28 \%)$. The effectiveness of the Triazoles fungicides may be attributed to their interference with the biosynthesis of fungal sterols and inhibit the ergosterol biosynthesis. In many fungi, ergo-sterol is essential to the structure of cell wall and its absence cause irreparable damage to cell wall leading to death of fungal cell. A similar study was reported for the effectiveness of Triazoles, which inhibit the sterol biosynthesis pathway in fungi (Nene and Thapliyal, 1973). Prashanth et al. (2008) reported that among four sys- 
temic fungicides maximum $\%$ inhibition of growth of C. gloeosporioides was observed in Difenconazole $(90.78 \%)$ and Propiconazole $(90.78 \%)$, Gud and Raut (2008) reported that Thiophenate-methyl and Propiconazole were most effective against $C$. gloeosporioides followed by Hexaconazole and Carbendazim. Patel (2009) and Pandey et al. (2012) studied that among the tested fungicides Tricyclazoles were found to be superior for controlling C. gloeosporioides causes anthracnose of mango.

At higher concentration (2000 ppm) most of the fungicides viz. Hexaconazole, Propiconazole, Penconazole, Tebuconazole, Carbendazim, Azoxystrobin, Difenoconazole, Thifluzamide and Trifluoxystrobin inhibited maximum mycelial growth but decreased with reduced concentration (500 ppm and $1000 \mathrm{ppm}$ ). These results are in agreement with that of Sudhakar (2000); Prashanth (2007); Patel (2009); Devamma et al. (2012) reported that among all the six fungicides evaluated against $C$. gloeosporioides the cause of mango anthracnose, the systemic fungicide Thiophanate-methyl (100 $\%)$ and the non-systemic fungicide Mancozeb (100\%) proved to be effective in inhibiting the mycelial growth of the highly virulent pathogen at $50 \mathrm{ppm}$ and $500 \mathrm{ppm}$ concentrations, respectively. Similarly, Pandey et al. (2012) studied the effect of different fungicides on the control of C. gloeosporioides causes anthracnose of mango. Among the tested fungicides Tricyclazoles were found to be superior for controlling the incidence of pathogen and Saju et al. (2012) reported the effectiveness of different fungicides against C. gloeosporioides infecting large cardamom, the in vitro tests showed that, the pathogen was highly sensitive to Copper oxychloride $50 \mathrm{WP}(0.3 \%)$ followed by Mancozeb 75 WP $(0.3 \%)$ and combined formulation of Carbendazim + Mancozeb $(12+63) \mathrm{WP}(0.3 \%)$.

Among the tested fungicides viz. contact/ combination product and systemic, most of the Triazoles and combination product fungicides given cent percent mycelial growth inhibition at all tested concentration. Therefore, this indicates that the systemic fungicides were found more effective as compare to contact fungicides in controlling fungal mycelial growth. Among the tested concentrations, higher concentrations of contact/ combination and systemic fungicides (1000 and $2000 \mathrm{ppm}$ ) were found to be more effective as compared to lower concentrations.

\section{Conclusion}

Chemical control is one of the indispensable approach of integrated disease management. However, there is lack of effective chemicals with suitable concentration against C. gloeosporioides causing anthracnose of pomegranate. Therefore, in this paper some new fungicide molecules (Systemics and non-systemics) has been tested under in vitro condition at different concentration (100, 250, 500, 1000 and 2000ppm). Among tested fungicides some viz. Hexaconazole + Zineb, Trifloxystrobin + Tebuconazole and non-systemic fungicide Captan and systemic fungicides viz. Carbendazim, Hexaconazole, Propiconazole, Penconazole and Tebuconazole shown cent percent mycelial growth inhibition of the fungus. Therefore, present studies provide some new chemical molecules which have been found effective in controlling C. gloeosporioides causing anthracnose of pomegranate. However, further evaluation of effective fungicides are needed in field for better recommendation for management of anthracnose of pomegranate.

\section{REFERENCES}

APEDA (2012). 'Area and production of pomegranate fruit', Retrieved from http://agriexchange.apeda.gov.in/India production/India_productions.aspx.

Barnett, H.L. and Hunter, B.B. (1972). Illustrated genera of imperfect fungi. Burgess Publishing Company. Minnesota, USA.

Devamma, M.N., Rajkumari, J.P. and Devi, P.S. (2012). Fungicide compatible potential biocontrol agents against Colletotrichum gloeosporioides Penz. causing mango anthracnose. Current Biotica, 5(4): 454-464

Ekbote, S.D., Padaganur, G.M. and Anahosur, K.H. (1996). In-vitro evaluation of fungicides against Colletotrichum gloeosporioides. Karnataka. J. Agric. Sci. 9(2): 359-360

Gud, M.A. and Raut, S.P. (2008). Control of mango anthracnose and stem end rot fungi by fungicides and bioagents. J. Maharashtra Agric. Uni., 33(1): 120-122

Jayalaxami, K. (2010). Studies on anthracnose of pomegranate caused by Colletotrichum gloeosporioides (Penz.) Penz \& Sacc. M.Sc. (Agri.) Thesis, Univ. Agril. Sci., Dharwad (India).

Nene, Y.L. and Thapliyal, A.J. (1973). Fungicides in plant disease control, III edition. Oxford and IBH Publishing Co. Pvt Ltd., New Delhi, p. 325.

Pandey, A., Yadava, L.P., Manoharan, M., Chauhan, U.K. and Pandey, B.K. (2012). Effectiveness of cultural parameters on the growth and sporulation of Colletotrichum gloeosporioides causing anthracnose disease of mango (Mangifera indica L.). OJBS, 12(4): 123-133

Patel, D.S. (2009). Chemical management of fruit spot of pomegranate caused byColletotrichum gloeosporioides Penz. and Sacc. Indian Phytopathol., 62(2): 252-253

Prashanth, A. (2007). Investigation on anthracnose (Colletotrichum gloeosporioides (Penz.) Penz. And Sacc.) of pomegranate (Punica granatum L.). M.Sc. (Agri.) Thesis, Uni. Agric. Sci., Dharwad (India).

Prashanth, A., Arun, R.S., Naik, M.K., Patil, M.B. and Rajesh, S.P. (2008). Evaluation of fungicides, bioagents, and botanicals against pomegranate anthracnose. Indian J. Plant Protec., 36(2): 283-287

Rangaswami, G. and Mahadevan, A. (1999). Diseases of crop plants in India. Prentice Hall of India Pvt. Ltd., New Delhi.

Saju, K.A., Deka, T.N., Gupta, U., Biswas, A.K. and Sudharshan, M.R. (2012). In vitro evaluation of biocontrol agents, botanicals and fungicides against Colletotrichum gloeosporioides infecting large cardamom. Pl. Dis. Res., 27(1): 49-53

Shravelle, V.G. (1961). The nature and use of modern fungi- 
Devanshu Dev and T. Narendrappa / J. Appl. \& Nat. Sci. 8 (4): 2268-2272 (2016)

cides. Burges Publication Company, Minneosota, USA, p. 308

Sudhakar, (2000). Biology and management of Stylosanthes anthracnose caused Colletotrichum gloeosporioides
(Penz). Penz. and Sacc. M.Sc. (Agri.) Thesis, Uni. Agric. Sci., Dharwad (India), pp. 34-35

Vincent, J.M. (1947). Distribution of fungal hyphae in the presence of certain inhibitors. Nature, 159: 850 